\title{
KRIPTOVALUTA BEFEKTETŐK INNOVÁCIÓ-ELFOGADÁSÁNAK VIZSGÁLATA
}

\author{
Tachscherer Balázs László - Benedek Andrea
}

\section{Összefoglalás}

Napjainkban már több mint 2100 kriptovalutát tartanak számon. Mindazonáltal az államok és a jegybankok többsége nem ismeri el a kriptovalutákat fizetöeszközként, söt számtalan alkalommal a kriptovalutákkal kapcsolatos veszélyekre hivják fel a figyelmet. A fogyasztói kockázatok, veszélyek ellenére az elmúlt években több millió tranzakciót inditottak kriptovalutákkal, a kriptovaluta befektetök száma is több millióra tehetö. 2009ben a bitcoin protokoll közzétételét követö évben, hazánkban csak egy nagyon szük réteg kezdett el érdeklödni a kriptovaluta befektetések iránt.

Kutatásunkban Everett Rogers diffúziós elméletét felhasználva arra keressük a választ, hogy a kriptovaluta befektetök mennyire nyitottak az innovációra, mennyire tartoznak az innovátorok (újítók) közé. Vizsgáljuk, hogy a kriptovaluta befektetök innováció elfogadással kapcsolatos véleményei között különbséget lehet-e tenni demográfiai jellemzök alapján.

Primer kutatásunk során kvantitativ jellegü, kérdöives felmérésre került sor a kriptovalutával rendelkezö befektetök körében.

A kutatás megállapitotta, hogy az általunk vizsgált kriptovaluta befektetök többsége - a Rogers-féle diffúziós elméletet alapul véve - az innovátorok (a minta háromnegyede), vagy késöi többség kategóriából kerül ki, akik fontosnak és szü̈ségesnek érzik az innovációt, mely hozzájárul a blockchain technológián alapuló üzleti modellek elterjedéséhez.

Ugyanakkor a vizsgálat eredményei cáfolták azt a hipotézist, mely korreláció mutatható ki az innováció elfogadása és a demográfia között.

Kulcsszavak: Bitcoin, kriptovaluta, befektetés, innováció, innovációterjedés JEL: G19, G23, O16 


\title{
RESEARCH FOR THE INNOVATION-APPRECIATION OF CRYPTO CURRENCY INVESTORS
}

\begin{abstract}
Nowadays, there are more than 2100 kinds of crypto currencies being kept counted. Nevertheless, most of the states (governments) and central banks do not admit crypto currencies as legal currencies, moreover, they draw attention to risks and dangers connected to crypto currencies a plenty of times. Despite consumers' risks and dangers, in the past years, more millions of transactions were released with crypto currencies, and the number of crypto currency investors can be appraised to more million people and/or companies as well. In the year 2009, meaning the year after publishing the Bitcoin Protocol, in our homeland, only a very small number of people, social classes started to pay attention towards crypto currency investments.

During our research, mainly using Everett Rogers' diffusion of innovation, we are searching for the answer to the question, whether how many crypto currency users are open-minded for innovation, how much they belong to the group of innovators. We research as well, whether a difference can be made between the opinions of crypto currency users regarding acceptance of crypto currencies, based on demographic features.

During our primary research, a quantitative-styled, questionnaire-based survey was made in the circle of primary investors, who dispose about crypto currencies.

The reasearch stated, that the majority of crypto currency investors surveyed by ourselves do represent - considering Everett Rogers' diffusion of innovation are three quarter of the category of innovators, or of late majority, who consider innovation as important and necessary, that contributes to the spread of blockchain-technology-based business models.

At the same time, the results of the survey confute the presumption, in accordance of which, a correlation can be detected between acceptance of innovation and demography.
\end{abstract}

Key words: Bitcoin, crypto currency, investment, innovation, spread of innovation JEL: G19, G23, O16 


\section{Bevezetés}

Satoshi Nakamoto japán fórumos 2009-ben megalkotta a Bitcoin (BTC) (bitérme) virtuális fizetőeszközt, 2013-ban pedig áttörés következett be a Bitcoin fejlődésében, az egyre nagyobb médiavisszhangnak köszönhetően jelentős árfolyamrobbanás ment végbe. A Bitcoin megjelenését és térhódítását számos egyéb, részben a Bitcoin technológiájára épülő altcoin követte. A blockchain technológián alapuló kriptopénzt, mint innovatív megoldást a világ számos pontján használják az emberek, azonban az eddigi 10 éves életciklusa alatt nem tudott egyetlen országban sem mindennapi fizetőeszközzé válni. Sokkal inkább spekulációs, vagyonfelhalmozási, jövedelemszerzési célokat szolgál a befektetők körében. Egy-egy innováció térbeli és időbeni elterjedése számos tényezőtől függ, így többek között a piactól, a felhasználók viselkedésétől, a gazdasági-, technológiai környezettől, a szabályozástól, stb. Kérdésként merül fel, hogy a kriptopénz befektetők mennyire nyitottak az innovációk iránt, ezáltal miként járulnak hozzá a blockchain technológia minél szélesebb körben történő elterjedéséhez.

\section{Everett Rogers diffúziós elmélete}

A kriptovaluta befektetők innováció elfogadásának megismeréséhez eredményesen alkalmazható módszer az innováció diffúziója elmélet. A módszert Everett M. Rogers amerikai szociológus dolgozta ki, egyben megalkotta a korai adaptáló fogalmat. Rogers (1962) a Diffusion of Innovations című könyvében publikálta elméletét. Rogers az innovációt olyan gyakorlatként, gondolatként, tárgyként határozza meg, amelyet az emberek újnak értékelnek. Az innovációkat alkalmazó embereket 5 kategóriába sorolja be úgy, mint újítók (innovátorok), korai adaptálók, korai többség, késői többség, valamint a lemaradók (Rogers, 1962). (1. ábra)

A Rogers-féle elmélet a diffúziós folyamat négy összetevőjét határozza meg, ezek az innováció, a kommunikációs csatorna, az idő, és a társadalmi rendszer. Rogers azokat a dimenziókat, tényezőket vizsgálja, amelyek befolyásolják az innováció elfogadásának, elterjedésének ütemét (Csizmadia, 2017). „Gondolkodásának alapja, hogy az innovációk használata az időben több fázison keresztül terjed el az egyes szegmensek használatba való bekapcsolódása révén" (Jakopánecz, 2015, 24. o.). A modell az egyének innováció elfogadását 5 lépésben határozza meg, ezek a tudatosság, az érdeklődés, az értékelés, a kipróbálás, valamint az alkalmazás (Savery, 2005). 


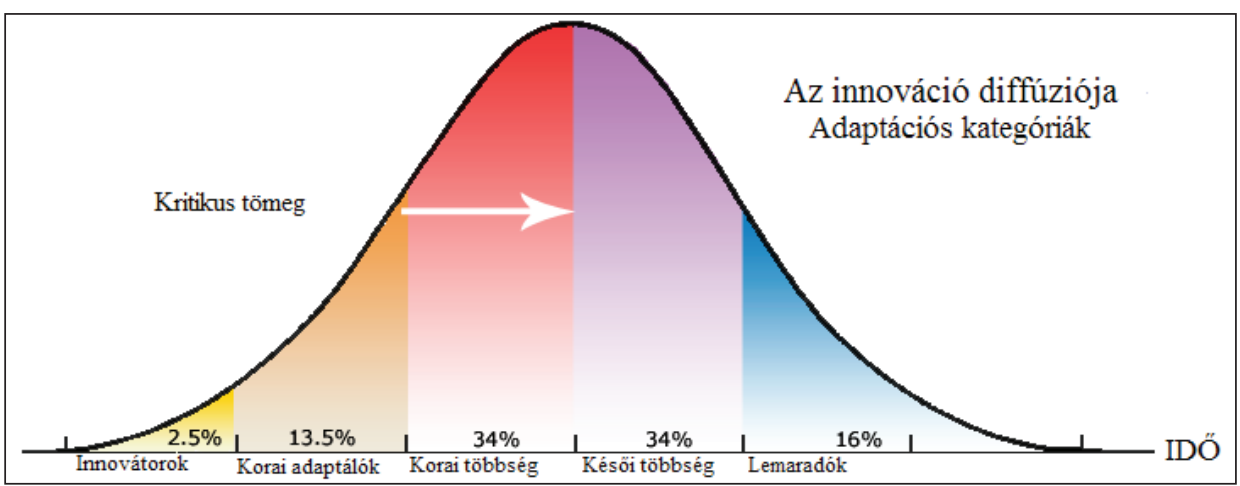

\section{1. ábra: Innovációk diffúziója}

forrás: Domschitz, 2013

Az innovációk elfogadásának, adaptálásának ütemét meghatározzák az adott innováció jellegzetességei, amelyeket a potenciális adaptálók szempontjából 5 kategóriába lehet sorolni úgy, mint relatív előny, kompatibilitás, komplexitás, kipróbálhatóság, megfigyelhetőség. A relatív előnyön azt értik, hogy az adott újítás milyen mértékben jobb, mint a már alkalmazott eljárás. A kompatibilitás arra mutat rá, hogy az innováció mennyire fér össze a potenciális alkalmazók értékrendjével, igényeivel, tapasztalataival. Komplexitás alatt azt értjük, hogy az adott újítás és alkalmazása mennyire közérthető. A kipróbálhatóság arra vonatkozik, hogy az innováció milyen módon, alapokon kísérletezhető ki. A megfigyelhetőség pedig arra vonatkozik, hogy az innováció eredményei mennyire átláthatóak, egyértelműek. Az innováció adaptálásának sebessége szoros összefüggésben van az egyes vizsgált tényezőkkel (Csizmadia, 2017).

Az innovációkkal kapcsolatos döntési folyamatok is 5 lépésből állnak, a tudásból, meggyőzésből, a döntésből, az alkalmazásból és a megerősítésből. Tudás akkor jöhet létre, ha az egyén tudomást szerez az újdonságról, és megérti annak müködését. Meggyőzés alatt az egyén véleménynyilvánítását értjük, amely lehet pozitív vagy negatív az innovációval kapcsolatban. „A döntés akkor megy végbe, amikor egy személy által megvalósított tevékenységek az innováció elfogadásához vagy elutasításához vezetnek" (Csizmadia, 2017, 52. o.). A megvalósulás akkor következik be, amikor a személy elkezdi használni, alkalmazni az adott innovációt. A megerősítés abban az esetben történik, ha az egyén az innovációval kapcsolatos korábbi döntését megerősíti (Csizmadia, 2017).

Rogers (1962) úgy gondolja, hogy az innovációk elfogadásában meghatározó szerepe van a véleményvezéreknek, a trendeknek, a különböző hálózatoknak. A véleményvezéreken keresztül az innováció további személyekhez jut el. Fontos megjegyezni, hogy a véleményvezérek az innovációkkal szemben nemcsak elfogadók lehetnek, hanem elutasítók is. 
Az innovációk elterjedésében nagy szerepe van a tömegkommunikációs csatornáknak, a potenciális alkalmazók ezeken a csatornákon keresztül szereznek tudomást, és információkat az újítás létezéséről. Az innovációk elterjedésében még jelentős szerepe van az időbeliségnek. „A diffúziós folyamat kezdetén viszonylag kevesen válnak felhasználókká, egy idő után megnövekszik a csatlakozók száma, majd újra csökkenni kezd" (Csizmadia, 2017, 54. o.). Az 1. ábra is mutatja, hogy akik az elsők között adaptálják az innovációkat, az összes alkalmazók 2,5 \%-át jelentik. Azok profitálhatnak a legtöbbet egy adott innovációból, akik a legkésőbb, utolsóként adaptálják.

A blokklánc technológián alapuló rendszerek, termékek, szolgáltatások, a folyamatosan megjelenő altcoinok napi szinten hordozzák az új innovációk megjelenését. A kriptovalutákba fektetőknek is meg kell ismerkedniük az új technológiákkal, elnevezésekkel, ugyanakkor kérdésként merül fel, hogy ezek a befektetők mennyire nyitottak az innovációk adaptálására. Ennek vizsgálatában lehet segítségünkre az ismertetett rogers-i diffúziós elmélet.

\section{Kriptovaluta elfogadással kapcsolatos nemzetközi felmérések}

A blokklánc mainstream elfogadottságát előmozdító Clovr vállalat 2018-ban, az Amazon Mechanical Turk Platformon keresztül kérdezett meg 1004 amerikait azzal kapcsolatban, hogy mit gondolnak a kriptopénzekről, illetve a kriptopénzekbe történő befektetésekről. A megkérdezettek $76 \%$-a tudja, hogy mi a kriptovaluta (Clovr, 2018). A válaszadók $60 \%$-a még mindig újdonságnak tekinti a kriptovalutákat. A befektetők egyharmada a kimaradástól való félelem miatt vásárolt kriptovalutát, míg 49 \%-a profit, a befektetés nagy megtérülése reményében döntött a vásárlás mellett. A válaszadók 17 \%-a a belső indíttatás hatására szánta rá magát kriptovaluta vásárlására (O’Brien, 2018). A felmérésben résztvevők 34 \%-a fektetett be kriptovalutába. A befekektetők jellemzően férfiak, 41 \%-a az Y generáció tagjai közül kerülnek ki, városi lakosok (42\%), és az átlagnál jobban élnek (viszonylag gazdagok) (43\%). A megkérdezettek $36 \%$-a gondolja úgy, hogy a befektetők innovátorok, ugyanakkor 22,3 \%-a meggondolatlannak tartotta őket. (Coincolors, 2018).

A Blockchain Capital nevében, a Harris Poll 2017. október 18-20. között, 2112 fó, 18 évnél idősebb amerikai bevonásával vizsgálta a lakosság Bitcoinnal kapcsolatos ismereteit, és érzékenységét. A megkérdezettek $2 \%$-a rendelkezett Bitcoinnal, míg 7 \%-a teljesen tisztában van vele, hogy mi a Bitcoin. A megkérdezettek 30 \%-a némileg ismeri a Bitcoint, ugyanakkor a válaszadók $23 \%$-a soha nem hallott róla. A megkérdezettek $34 \%$-a gondolja úgy, hogy a Bitcoin egy pozitív innováció a pénzügyi technológiákban, $26 \%$-a ennek ellenkezőjét állítja. A válaszadók 18 \%-a megbízhatóbbnak tartotta a Bitcoint, mint a nagy bankokat. A megkérdezettek $9 \%$-a értett 
egyet azzal az állítással, hogy az emberek többsége 10 éven belül használni fogja a Bitcoint. A válaszadók 19 \%-a gondolja úgy, hogy az elkövetkező 5 évben fog Bitcoint vásárolni (Blockchain Capital, 2017).

A fentiekből jól látható, hogy az elmúlt egy-két évben ugyan végeztek felméréseket a lakosság kriptovalutákkal kapcsolatos ismereteivel, elfogadásával összefüggésben, azonban a kriptovalutákba fektetők innováció-elfogadásának mérésére irányuló konkrét kutatást nem találtunk.

\section{Anyag és módszer}

A tanulmány célja a kriptovaluta befektetők innováció elfogadásának vizsgálata. $\mathrm{Ku}-$ tatásunk során nem találtunk olyan szakirodalmat, kutatást, tanulmányt, amelyik a kriptovalutákba fektetők innováció-elfogadásával foglalkozott volna, ugyanakkor úgy gondoljuk, hogy Roberts innovációs elmélete alkalmas lehet arra, hogy a diffúziós folyamat négy alapvető összetevőjén keresztül közelebb kerüljünk a hazai befektetők innováció-adaptálásának megismeréséhez. A tanulmány primer kutatásán keresztül az említett űrt kívánjuk pótolni. A következő kutatási kérdéseket fogalmaztuk meg:

K1: Mennyire nyitottak a kriptovaluta befektetők az újításokra?

K2: Milyen adaptációs kategóriába sorolhatók a kriptovaluta befektetők?

A kriptovaluta befektetők innováció elfogadásának vizsgálatára a szakirodalmi áttekintésben ismertetett Rogers innovációs elméletével került sor. Savery (2005) alkalmazta a Rogers diffúziós modellt a PR-szakemberek innovációs szintjének vizsgálatára. Úgy gondoltuk, hogy a kriptovaluta befektetők az innovátorok csoportba sorolhatók, ezért választottuk a Rogers modellt. A rogers-i elvek alapján a vizsgálatoknál tíz állítást fogalmaztunk meg, melyeket összevonva öt csoportot hoztunk létre: innovátorok, korai adaptálók, korai többség, késői többség, lemaradók. A kérdések összevonását ugyanúgy végeztük el, ahogy Savery (2005) tette azt, azaz a két kérdésre adott válaszok számtani átlagát vettük. A kapott adatokból különböző módszerek alkalmazásával vizsgálatokat végeztünk.

Primer kutatás keretében kérdőíves felmérésre került sor. A 16 kérdést tartalmazó kérdőív kitöltésére online módon, a kerdoivem.hu weboldalon nyílt lehetőség. A kérdőív kitöltésére különböző, kriptovalutákhoz köthető Facebook csoportokban, valamint fórumokon invitáltuk a kriptovalutákba fektető tagokat. A kérdőív kitöltésére 2019. február 17. és március 21. között volt lehetőség. A kérdőívet 214 fö töltötte ki, a minta elemszáma végül n = 210 fö lett. A minta meghatározásakor kritérium volt, hogy a megkérdezettek rendelkezzenek valamilyen formában kriptovaluta befektetéssel. 
Három kérdéskör feltevésével azt vizsgáltuk, hogy a befektetők mennyire nyitottak az újításokra. Az egyes kérdéskörök 10-10-7 állítást tartalmaztak, melyeket 4 fokozatú Likert-skálán tudtak a válaszadók értékelni aszerint, hogy mennyire jellemzi őket az adott állítás (ahol 1 = egyáltalán nem jellemző, 4 = nagyon jellemző). A kérdőívek kiértékeléséhez Microsoft Excelt, és SPSS programcsomagot használtunk. A kapott eredményeket diagramokon ábrázoltuk.

Kolmogorov-Smirnov normalitásvizsgálatot alkalmaztunk a normális eloszlás vizsgálatára, valamint a további elemzési módszerek meghatározásához. A vizsgálatok eredményét befolyásoló statisztikai hibák kiszűrését is fontosnak tartottuk. A normalitásvizsgálat során megállapítható volt, hogy sem az eredeti itemek, sem a képzett változók nem követnek normális eloszlást. Különböző vizsgált paraméterekre (nem, iskolai végzettség, kor) statisztikai hipotézisvizsgálatot készítettünk. A férfiak és nők innováció elfogadása közötti összefüggéseket Mann-Whitney teszttel, míg az iskolai végzettség, és a kor szerinti összehasonlítást Kruskal-Wallis teszttel végeztük el. Vizsgáltuk, hogy a felmérésben részt vevő személyek „innováció” szempontból felbonthatóak-e viszonylag homogén csoportokra, és megfigyelhető-e a kialakított klaszterek között a többi változóban szignifikáns különbség. Először egy hierarchikus klaszterelemzést, majd k-közép klaszterelemzést készítettünk.

\section{Eredmények}

A kérdőíves felmérésben 144 férfi és 66 nő vett részt. A válaszadók aránya nemenként a következő: 68,60 \% férfi, 31,40 \% nő. A kriptovaluta befektetők életkorát illetően a 30-40 év közötti korosztály tagjai közül kerültek ki a legnagyobb arányban, azonban tőlük nem sokkal maradtak el a 41-50 év közötti korosztály képviselői. Talán meglepő, hogy az 51 év feletti korosztály tagjai 25,71 \%-ot képviselnek a vizsgált mintán belül. A megkérdezett kriptovaluta befektetők túlnyomó többsége iskolai végzettség alapján két csoportba osztható úgy, mint középfokú végzettséggel rendelkező (44,8 \%), és felsőfokú végzettséggel rendelkező (föiskola, egyetem) (43,3 \%). Az életszínvonalukat megítélők túlnyomó része jobban, vagy sokkal jobban él, mint az átlag magyar állampolgár, azonban a válaszadók 40 \%-a nem tudta megállapítani, hogy az átlag állampolgárhoz képest miként él.

Vizsgáltuk, hogy a megkérdezettek a kérdések kombinálása alapján hogyan jellemzik önmagukat innovációs szint szempontjából. A percentilisekből leolvasható a véleményük. (2. ábra) A 3 vagy afeletti értékhez tartozó percentilisek azt jelzik, hogy inkább egyetértenek, a 3 alattihoz kapcsolódók, hogy nem. A megkérdezettek 74,30\%-a tartja magát innovátornak, korai adaptálónak már csak 41,4\%. Korai többségként jellemezte magát a kriptovaluta befektetők 67,6\%-a, késői többségként 
94,8\%-a, lemaradóként kevesebb, mint 10\%-a. A kriptovaluta befektetés jellegéből következik: az új technológia elfogadása egyszerre jelentheti, hogy valaki innovátornak tekinti magát, követi, szükségszerünek tartja az innovációt, viszont ebben nem akar másokat befolyásolni.

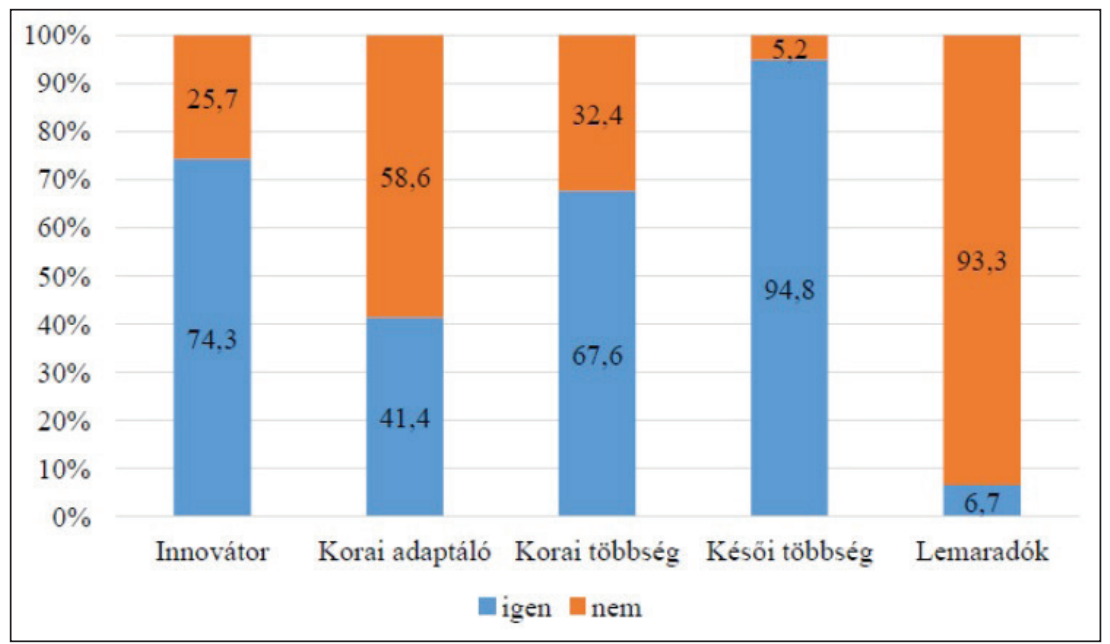

\section{2. ábra: Kombinált mutatók szerinti megoszlások}

forrás: saját szerkesztés, standard kérdöives megkérdezés alapján, $n=210$, 2019. február-március (3-4 = igen, 1-2 = nem)

Megvizsgáltuk, hogy megfigyelhető-e különbség valamely kombinált mutató esetén a férfiak és nők önértékelése között. A hipotézisvizsgálatot Mann-Whitney teszttel végeztük el, mivel a változók nem normál eloszlásúak. Megállapítható, hogy egyik esetben sem tér el a férfiak és a nők érékelése egymástól. A következő szempont az összehasonlításkor az volt, hogy az iskolai végzettség befolyásolja-e a kialakított véleményeket, azonban e tekintetben sem figyelhető meg szignifikáns eltérés. A vizsgálatot Kruskal-Wallis teszttel végeztük el, 0,05-ös szignifikancia szint mellett. A szignifikancia szintek a következőképpen alakultak: innovátorok $\mathrm{p}=0,409$, korai adaptálók $p=0,624$, korai többség $p=0,465$, késői többség $p=0,098$, lemaradók $p=0,332$. Ezt követően korcsoportokat alakítottunk ki: 30 év alattiak, 30-40 év közöttiek, 4150 év közöttiek, 51-60 év közöttiek és 60 év felettiek. A vizsgálatot Kruskal-Wallis teszttel végeztük el, 0,05-ös szignifikancia szint mellett. Azt elemeztük, hogy a kor befolyásolja-e az innovációs szintet, azonban ez alapján sem állapíthatók meg statisztikailag is igazolható különbségek. A szignifikancia szintek a következőképpen alakultak: innovátorok $\mathrm{p}=0,963$, korai adaptálók $\mathrm{p}=0,350$, korai többség $\mathrm{p}=0,880$, késői többség p=0,485, lemaradók p=0,656. 
Megvizsgáltuk, hogy a megkérdezettek „innovátor” szempontból felbonthatóak-e viszonylag homogén csoportokra és megfigyelhető-e az így kialakított klaszterek között a többi változóban szignifikáns különbség. Először egy hierarchikus klaszterelemzést futtattunk, hogy vizuális képet kapjunk a kialakítható csoportok számáról (3. ábra). Jól látható, hogy több szinten kapcsolódnak a vélemények. A dendogram felső szintjeit vizsgálva 3, 4 vagy 5 jól elkülöníthető ág választható ki. Végül a 3, 4 és 5 lehetséges csoportot tartalmazó lehetőséget vizsgáltuk k-közép klaszterelemzéssel.

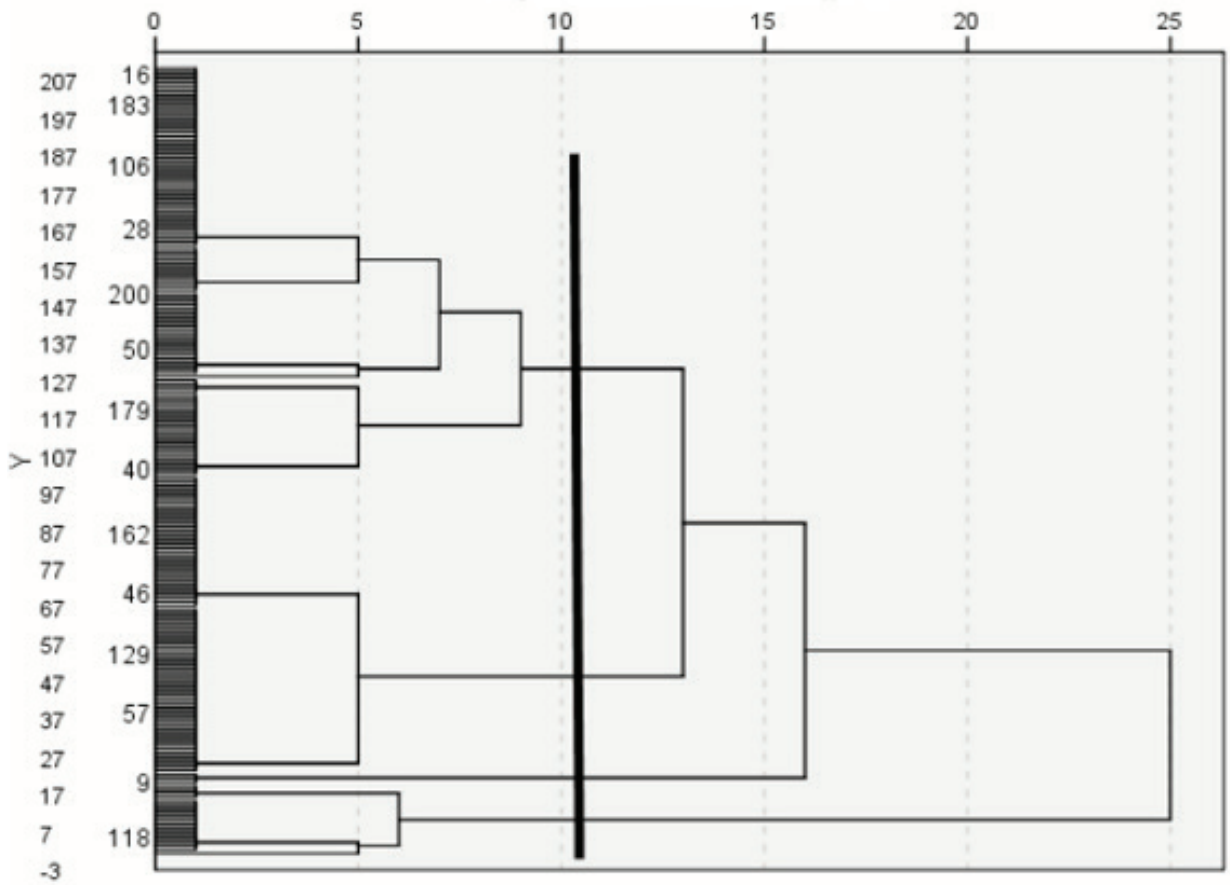

\section{3. ábra: Az „,innovátor” itemjeire elkészített hierarchikus klaszterelemzés dendogramja} forrás: saját szerkesztés, standard kérdöives megkérdezés alapján,

$$
n=210 \text {, 2019. február-március }
$$

A k-közép klaszterelemzés során 4 klaszteres csoportosítás eredményeként kaptuk a legkiegyenlítettebb létszámú klasztereket, azonban nem volt minden csoport között szignifikáns különbség. Végül a három klaszterre bontás után már jól elkülöníthető csoportosítás jött létre. (1. táblázat) 
Tachscherer Balázs László, Benedek Andrea

\begin{tabular}{|c|c|}
\hline Rogers-féle adaptációs csoportok & Általam képzett adaptációs csoportok \\
\hline Innovátor & Cryptocurrency innovátor \\
\hline Korai adaptáló & Medium cryptocurrency innovátor \\
\hline Korai többség & Less cryptocurrency innovátor \\
\hline Késői többség & \\
\hline Lemaradók & \\
\hline
\end{tabular}

1. táblázat: Adaptációs csoportok

forrás: saját számitás, standard kérdöives megkérdezés alapján, $n=210$, 2019. február-március

A kialakított klaszterek átlagait, mediánjait és esetszámait a 2. táblázat tartalmazza mindegyik komplex innovációs mutatónál. Az 1. klaszterbe került személyek tekinthetők a leginnovatívabbnak (őket cryptocurrency innovátornak neveztük el), itt a legmagasabb az átlag és a medián az innovátor dimenzióban. A 3. klaszter van a második helyen és az utolsó helyen 2 klaszter. Fentiek alapján a következő csoportok alakíthatók ki: 1. klaszter: cryptocurrency innovátor, 3. klaszter: medium cryptocurrency innovátor, 2. klaszter: less cryptocurrency innovátor.

\begin{tabular}{|r|r|r|r|r|r|r|}
\hline klaszter & N (fó) & Innovátor & Korai adaptáló & Korai többség & Késői többség & Lemaradók \\
\hline 1 & 67 & $3,8 / 4$ & $3,1 / 3$ & $3,1 / 3$ & $3,6 / 4$ & $2,5 / 2,5$ \\
\hline 2 & 121 & $2,8 / 3$ & $2,3 / 2$ & $3 / 3$ & $3,5 / 3,5$ & $2 / 2$ \\
\hline 3 & 22 & $3,3 / 3,5$ & $2,5 / 2,3$ & $2,9 / 3$ & $3,7 / 3,5$ & $1,5 / 1,5$ \\
\hline
\end{tabular}

2. táblázat: A kialakított klaszterek létszáma, az átlagpontok és mediánok (átlag/medián)

forrás: saját számitás, standard kérdöives megkérdezés alapján,

$$
n=210,2019 \text {. február-március }
$$

A cryptocurrency innovátor csoport közel a harmadát teszi ki a megkérdezett személyeknek. A legnagyobb klaszter az összes mintaelemszám felét jóval meghaladóan a less cryptocurrency innovátorok csoportja, míg a medium cryptocurrency innovátorok száma csak 22 fó.

Elemeztük, hogy a klaszterek között megfigyelhető-e szignifikáns különbség az innovátorok, a korai adaptálók, a korai többség, a későbbi többség és a lemaradók dimenzióiban. A vizsgálatot $5 \%$-os szignifikancia szinttel végeztük. A szignifikancia szintek a következőképpen alakultak: innovátorok p=0,000, korai adaptálók p=0,000, korai többség $p=0,628$, késői többség $p=0,119$, lemaradók $p=0,000$. A vizsgálatokat Krus- 
kall-Wallis teszttel végeztük. A teszteredmények közül a korai és késői többség változók esetén nem mutatható ki szignifikáns különbség a klaszterek között. A szignifikáns különbséget mutató komplex változók esetén elvégeztük a klaszterek páros összehasonlítását is Dunn-teszt segítségével.

Innovátor: $\mathrm{Az}$ innovátoroknál az összes klaszterpárosításban szignifikáns eltérés mutatható ki, tehát az előzőekben feltüntetett klaszter sorrend statisztikailag is alátámasztott. Korai adaptáló: A 2-3 klaszterek között nincs igazolható különbség, a többi párosításban igen. Lemaradók: A lemaradók változónál mindegyik klaszterpárosításban szignifikáns különbség tapasztalható. Összefoglalva a páronkénti összehasonlítások eredményeit, megállapítható, hogy az innovátor változóba tartozó két item alapján létrehozott 3 klaszterbe tartozó személyek innovációs önértékelésének magyarázatába a korai és késői többség változókat nem tudjuk bevonni, mert a különböző szintu” „innovátor csoportok” mediánjai között nincs statisztikailag is igazolható különbség.

Az 1. klaszterbe tartozók az innovátor és korai adaptáló változókban is szignifikánsan magasabbra értékelték az innovációs szintjüket. Ennek némileg ellentmond, hogy a lemaradóknál is ők érték el a legmagasabb pontszámot, hisz ezeknél a kérdéseknél inkább alacsonyabb pontszámokra számíthatnánk, mert kicsit ellentmondásosnak tünik, hogy az újításokat folyamatosan kereső ember ellenáll a változásoknak. Az ellentmondást enyhíti, hogy a medián 2,5 a klaszterben, ami azt jelenti, hogy a klasztertagok több mint fele valamilyen szinten nem értett egyet az állításokkal, és határozottan kijelenthetjük, hogy az 1. klaszter tagjai újítók és adaptálók. Innovációs szint szempontjából második helyre került a 3. klaszter, viszont az őt követő 2. klasztertől csak abban különbözik, hogy itt szignifikánsan alacsonyabb a lemaradók kérdés itemjeire egyetértő választ adók aránya. A szignifikáns eltéréseket a klaszterek páronkénti összehasonlításánál a 3. táblázat mutatja, sárga színnel jelöltem a szignifikáns klaszterpárosításokat.

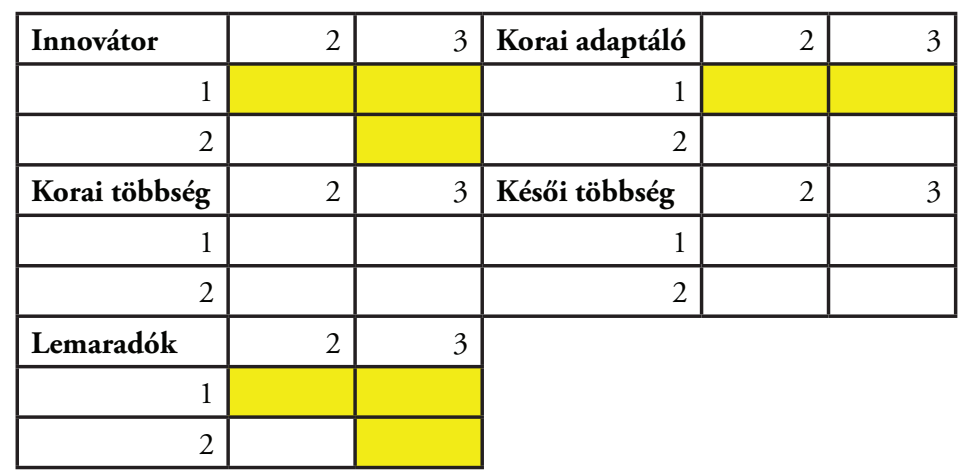

3. táblázat: Szignifikáns eltérések a klaszterek páronkénti összehasonlításánál forrás: saját számitás, standard kérdöives megkérdezés alapján, $n=210$, 2019. február-március (Sárgával jelölt klaszterpárositások szignifikánsak) 


\section{Következtetések}

Összességében megállapítható, hogy a kriptovaluta befektetők többsége az innovátorok, vagy késői többség közé sorolható, a legkevésbé jellemző rájuk a lemaradók adaptációs kategória. A vizsgálatok kimutatták, hogy nem figyelhető meg eltérés az innováció elfogadással kapcsolatos vélemények tekintetében a befektetők neme, életkora, és iskolai végzettsége alapján (nem volt szignifikáns eltérés). A kriptovaluta befektetők közel háromnegyede innovátornak tartja magát, nyitott az innovációra, és szükségszerűnek is tartja az innovációt. Véleményünk szerint a kriptovalutákba fektetők hozzájárulnak a blockchain technológián alapuló üzleti modellek elterjedéséhez.

\section{Hivatkozott források}

[1.] Blockchain Capital (2017): Bitcoin Survey Fall 2017. Letöltés dátuma: 2019. március 27. Forrás: www.blockchain.capital: http://www.survey.blockchain. capital/\#1509360090206-d2f853be-dec9

[2.] Clovr (2018): How Do Americans Feel About Cryptocurrency? Letöltés dátuma: 2019. március 23. Forrás: www.clovr.com: https:/www.clovr.com/ page/emotional-currency

[3.] Coincolors (2018): Főleg fiatal és gazdag férfiak fektetnek kriptopénzekbe. Október 8. Letöltés dátuma: 2019. március 27. Forrás: www.coincolors. co: https://coincolors.co/2018/10/08/foleg-fiatal-es-gazdag-ferfiak-fektetnek-kriptopenzekbe/

[4.] Csizmadia P. (2017): Everett Rogers innovációs elmélete és annak felhasználási lehetőségei az egészségfejlesztésben. Egészségfejlesztés. LVIII. évf. 4. sz. 50-58. o.

[5.] Domschitz M. (2013): Ki jár jól az információra alapuló társadalomban? Újítók és lemaradók. (Innováció 6). December 16. Letöltés dátuma: 2019. március 27. Forrás: www.hetedikvilag.blog.hu: https://hetedikvilag.blog. hu/2013/12/16/korai_ujitok_es_lemaradok_avagy_ki_jar_jol_az_innovaciora_alapulo_tudastarsadalomban

[6.] Jakopánecz E. (2015): A fogyasztói ellenállás. Doktori értekezés. Pécsi Tudományegyetem Közgazdaságtudományi Kar Gazdálkodástani Doktori Iskola, Pécs. 
[7.] O’Brien, K. (2018): Survey: Crypto investors lean towards innovation and novel thinking. Október 7. Letöltés dátuma: 2019. március 27. Forrás: www. bitcoinist.com: https://bitcoinist.com/crypto-investors-lean-towards-innovation-and-novel-thinking/

[8.] Rogers, M. E. (1962): Diffusion of Innovations. Free Press of Glencoe, New York.

[9.] Savery, A. C. (2005): Innovators or Laggards: Surveying Diffusion of Innovations by Public Relations Practitioners. Thesis. The Graduate Faculty of The University of Akron, Akron.

\section{Szerzők:}

\section{Tachscherer Balázs László}

Közgazdász, vezetés- és szervezés

tachscherer@gmx.de

\section{Benedek Andrea Ph.D}

adjunktus

Eszterházy Károly Egyetem, GYKRC

3200 Gyöngyös, Mátrai u. 36

benedek.andrea@uni-eszterhazy.hu 